\title{
An Electron Microscopic Study of a Transplantable Thyrotropic Pituitary Tumor in Mice
}

\author{
GAIKo UEDA \\ Department of Obstetrics and Gynecology \\ Osaka University Medical School, Osaka
}

Synopsis

\begin{abstract}
A transplantable thyrotropic pituitary tumor ( $\mathrm{TtT} 97)$ in mice and its responsiveness to thyroxine were studied by electron microscopy.

The secretory granules in the tumor cells of the dependent variant were usually more abundant than those in the autonomous tumor cells. In a response to thyroxine, the secretory granules in the dependent tumor cells were initially increased but subsequently decreased in number. In the autonomous tumor cells, no changes were observed after thyroxine treatment.

A few cells containing larger secretory granules were incidentally found in the dependent variant which showed a marked gonadotropic activity. It is therefore suggested that the thyrotropic pituitary tumor of mice might be another example of a mixed tumor, leaving many questions to be answered.
\end{abstract}

Thyrotropic pituitary tumors $\left(\mathrm{TtT}^{\prime} \mathrm{s}\right)$ were induced by radiothyroidectomy in mice (Gorbman, 1949; Furth and Clifton, 1966). They were at first transplantable only to athyroid isologous mice, but some of them grew also in normal hosts after further subpassages. The former were called dependent tumors, the growth of which could be prevented by thyroxine administration. They caused a marked stimulation of the gonads in athyroid hosts, but the proper explanation was lacking (Furth, 1954). The latter, autonomous tumors, produced specifically an extraordinary hyperplasia of the thyroid glands in intact hosts, which developed a series of thyroid tumors (Haran-Ghera et al., 1960; Sinha et al., 1965; Ueda and Furth, 1967).

In this paper, $\mathrm{TtT}^{\prime} \mathrm{s}$ with a gonadotropic activity were studied by electron microscopy with special reference to the responsiveness to thyroxine administration.

Received for publication January 20, 1971.

\section{Materials and Methods}

A TtT strain named TtT97 was established in $\mathrm{LAF}_{1}$ mice in Dr. Furth's laboratory. The dependent variant grew only in athyroid hosts and showed a marked stimulation of their ovaries. The autonomous one grew also in euthyroid hosts and caused a slight or moderate hyperplasia of their thyroid glands. To test the responsiveness of the $\mathrm{TtT}^{\prime} \mathrm{s}$ to thyroid hormone, the hosts were given daily doses of $10 \mu \mathrm{g}$ thyroxine intraperitoneally for 1 to 7 days when the grafted TtT97 grew about $1 \mathrm{~cm}$ across.

The tumors were prefixed in $5 \%$ glutaraldehyde for $2 \mathrm{hr}$ and washed at $4{ }^{\circ} \mathrm{C}$ for $24 \mathrm{hr}$ in $0.1 \mathrm{M}$ phosphate buffer ( $\mathrm{pH}$ 7.4) containing $0.2 M$ sucrose (Sabatini et al., 1963). They were refixed for 2-4 hr in $2 \%$ buffered osmium tetroxide containing sucrose (Caulfield, 1957). After dehydration in increasing concentrations of ethanol, they were embedded in Epon (Luft, 1961). The ultrathin sections were stained in $1-2 \%$ uranyl acetate solution for $3 \mathrm{hr}$ (Watson, 1958) and examined by electron microscopy.

\section{Results}

The $\mathrm{TtT}^{\prime}$ s were almost exclusively composed 
of the cells containing small secretory granules measuring up to $150 \mathrm{~m} \mu$ in diameter, which were considered to be characteristic of the basophils secreting thyroid stimulating hormone (TSH). These granules in the tumor cells of the autonomous variant (Fig. 1) were usually less in number than those in the dependent tumor cells (Fig. 2). In the dependent variant the cells containing larger secretory granules about $250 \mathrm{~m} \mu$ in diameter were incidentally found (Fig. 3).

One day after thyroxine administration, small secretory granules in $\mathrm{TtT}$ cells were markedly increased throughout the cytoplasm (Figs. 4 and 5) The vesicular structures were also conspicuous in these cells. Seven days later, however, count of these secretory granules rather decreased but was still more than in controls (Fig. 6).

\section{Discussion}

The responsiveness of normal thyrotropic cells to thyroxine has been studied in rats by light and electron microscopy (Peters and Halmi, 1961; Saki, 1962). They reported the initial accumulation of the secretory granules in the cytoplasm with a subsequent decrease in number because of the inhibition of hormone synthesis. Likewise, the growth of the dependent TtT cells in mice was inhibited by thyroxine administration (Gadsden and Furth, 1953). The marked decrease of the secretory granules in the thyrotropic component of a mixed tumor in rats was observed after thyroxine treatment for a prolonged period by electron microscopy (Ueda and Mori, 1967). In accordance with these data, it was shown in the present study that the secretory granules in the dependent TtT cells initially accumulated and subsequently decreased on thyroxine administration. The autonomous tumor cells did not respond to thyroxine. The similarities in responsiveness to thyroxine between the dependent TtT cells and normal thyrotropic cells are very interesting in rela- tion to the hormonal treatment of the tumors in the endocrine organs in general.

The gonadotropic side activities of $\mathrm{TtT}^{\prime} \mathrm{s}$ have been reported in the host mice (Furth, 1954). The level of gonadotropic activities in the tumor tissue, however, was very low and could not be detected by conventional bioassays (Furth and Clifton, 1966). Laron et al. (1970) recently reported a case of hypothyroidism with gonadal stimulation which had the elevated plasma gonadotropins measured by radioimmunoassay in the absence of urinary gonadotropins measured by bioassay. They considered the gonadotropic activity to be due mainly to follicle stimulating hormone on the basis of histological changes of the gonads. Since TSH and gonadotropins are different hormones, it seems reasonable to expect that different types of cells were present in this case. The situations seem somewhat similar to the mouse $\mathrm{TtT}^{\prime} \mathrm{s}$ under discussion, although radioimmunoassay of the plasma gonadotropins was not done in the present study.

Before discussing the mouse $\mathrm{TtT}^{\prime}$ s further, some reports on pituitary mixed tumors will be briefly reviewed. A mixed pituitary tumor being composed of both mammosomatotropic and thyrotropic cells was described by the authors, from which mammosomatotropic tumor (MStT) and TtT lines were selected successfully to some extent by the hosts conditioned (Ueda and Mori, 1967). The tumor cells seemed hormone-dependent at least in the earlier subpassages. The same phenomenon was reported by Schelin (1969) who explained it from a different viewpoint that two types of cells in the pituitaries could proliferate simultaneously under the influecce of hormonal derangement such as thyroidectomy and estrogen treatment. MStT induced with estrogen was also shown to be a type of mixed tumor (Ueda et al., 1968 and 1970). Based on the changes of the cells containing growth hormone ( $\mathrm{CH}$ cells) in the estrogeninduced pituitary tumors, the transformation of nonfunctional $\mathrm{GH}$ cells to functional ones 
during the serial transplantations was suggested. GH cells seemed hormonally independent after the tumors had become stabilized.

Let us go back to the mouse $\mathrm{TtT}^{\prime}$ s under discussion. The gonadotropic side activity in the mouse $\mathrm{TtT}^{\prime}$ s went hand in hand with the presence of $\mathrm{TtT}$ cells and was not inhibited with diethylstilbestrol (DES). Thus, TSH elaborated by the $\mathrm{TtT}^{\prime} \mathrm{s}$ was considered to have the dual properties (Messier, 1966). However, the incidental finding of the cells with larger secretory granules in the present study suggests that the mouse $\mathrm{TtT}^{\prime}$ s might be another example of a mixed tumor. Although these cells were not proved to be gonadotrophs but might rather be somatotrophs, it seems not impossible to expect that the autonomous gonadotrophs were admixed in the tumors which were responsible for the stimulation of the host gonads and not inhibited with DES. Many questions still remain to be answered. To explore the possibility that the mouse $\mathrm{TtT}^{\prime}$ s might be contaminated with gonadotrophs, an immunohistochemical study with peroxidase-labeled antibody is now under consideration.

\section{Acknowledgments}

The author expresses his thanks to Prof. Y. Ashitaka for reading this manuscript and also to Dr. J. Furth of Columbia University, New York City, for supplying the materials.

\section{References}

Caulfield, J. B. (1957). J. Biophys. Biochem. Cytol. 3, 827.
Furth, J. (1954). Amer. J. Path. 30, 421.

Furth, J. and K. H. Clifton. In The Pituitary Gland. Vol. II. Harris, G. W. and B. T. Donovan, eds. Butterworth, London, p. 416 (1966).

Gadsden, E. L. and J. Furth (1953). Proc. Soc. Exptl. Biol. 83, 511.

Gorbman, A. (1949). Ibid. 71, 237.

Haran-Ghera, N., P. Pullar and J. Furth (1960). Endocrinology 66, 694.

Laron, Z., M. Karp and L. Dolberg (1970). Acta Poediat. Scand. 59, 317.

Luft, J. H. (1961). J. Biophys. Biochem. Cytol. 9, 409.

Messier, B. (1966). Cancer Res. 26, 479.

Peters, B. H. and N. S. Halmi (1961). Endocrinology 68, 844.

Sabatini, D. D., K. Bensch and R. J. Barrnett (1963). J. Cell Biol. 17, 19.

Saki, T. (1962). Med. J. Osaka Univ. 12, 233.

Schelin, U. (1969). Acta path. microbiol. scand. 75, 537.

Sinha, D., R. Pascal and J. Furth (1965). Arch. Path. 79, 192.

Ueda, G. and J. Furth (1967). Ibid. 83, 3.

Ueda, G. and T. Mori (1967). Amer. J. Path. $\mathbf{5 1}, 601$.

Ueda, G., J. Otsuka, T. Mori and K. Nagai (1968). Wakayama Med. Rep. 13, 49.

Ueda, G., O. Tanizawa, H. Hamanaka and H. Nishiura (1970). Endocrinol. Japon. (jn press).

Watson, M. L. (1958). J. Biophys. Biochem. Cytol. 4, 475. 
Fig. 1. Showing TtT cells of the autonomous variant with small secretory granules (100 to $150 \mathrm{~m} \mu$ in diameter) in the cytoplasm. $\times 10,000$

Fig. 2. Showing TtT cells of the dependent variant bearing more abundant secretory granules than the autonomous tumor cells. $\times 10,000$ 

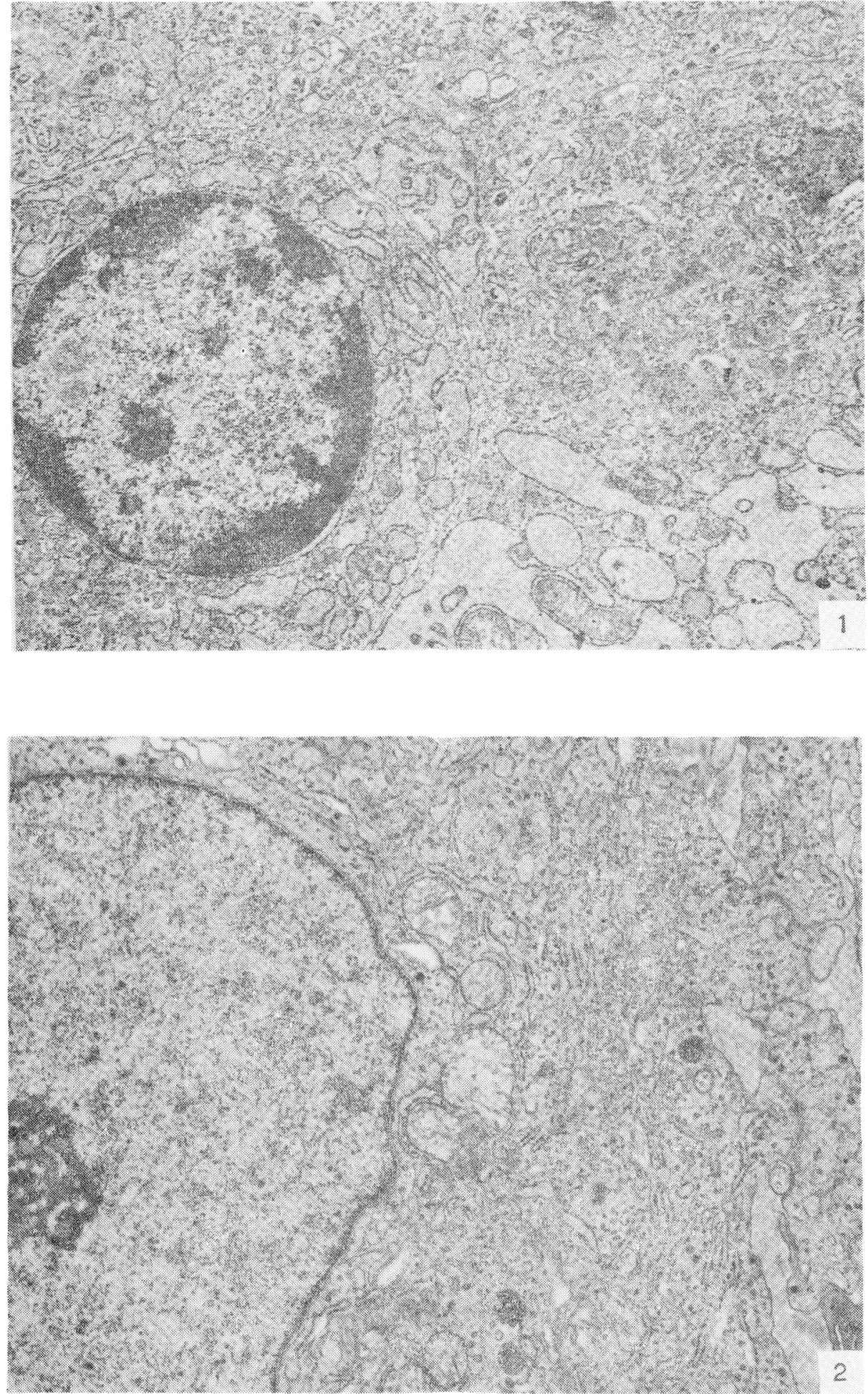
Fig. 3. Showing the cells with larger secretory granules (200 to $300 \mathrm{~m} \mu$ in diameter) in the cytoplasm. $\times 10,000$

Fig. 4 and 5. The secretory granules in the dependent TtT cells were markedly increased one day after thyroxine treatment. The vesicular structures were conspicuous, especially in Figure $5 . \times 10,000$ 

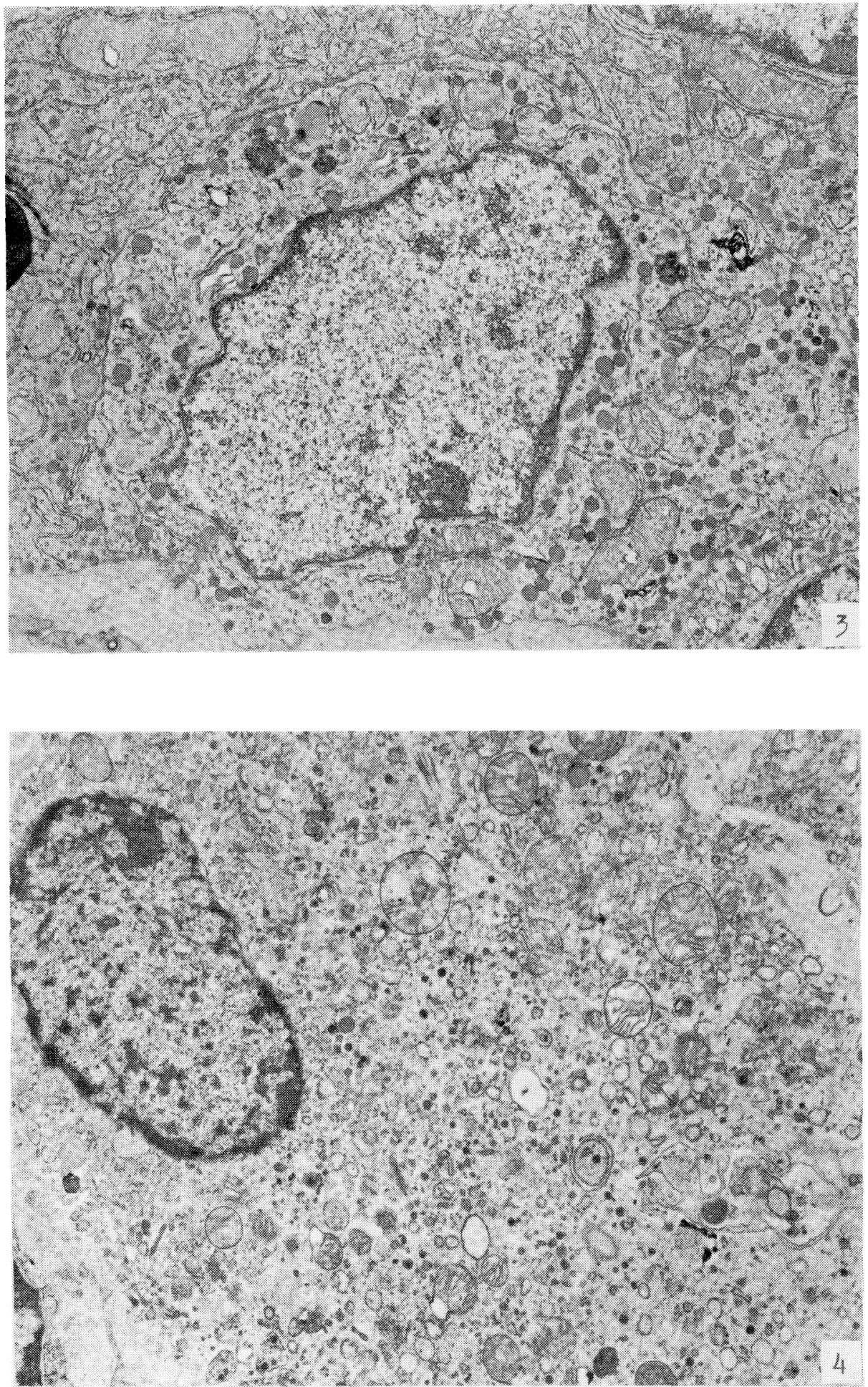
Fig. 6. Seven days after thyroxine treatment, the secretory granules in the dependent $\mathrm{TtT}$ cells were decreased in number but still more than in controls as showin in Figure 2. $\times 10,000$ 

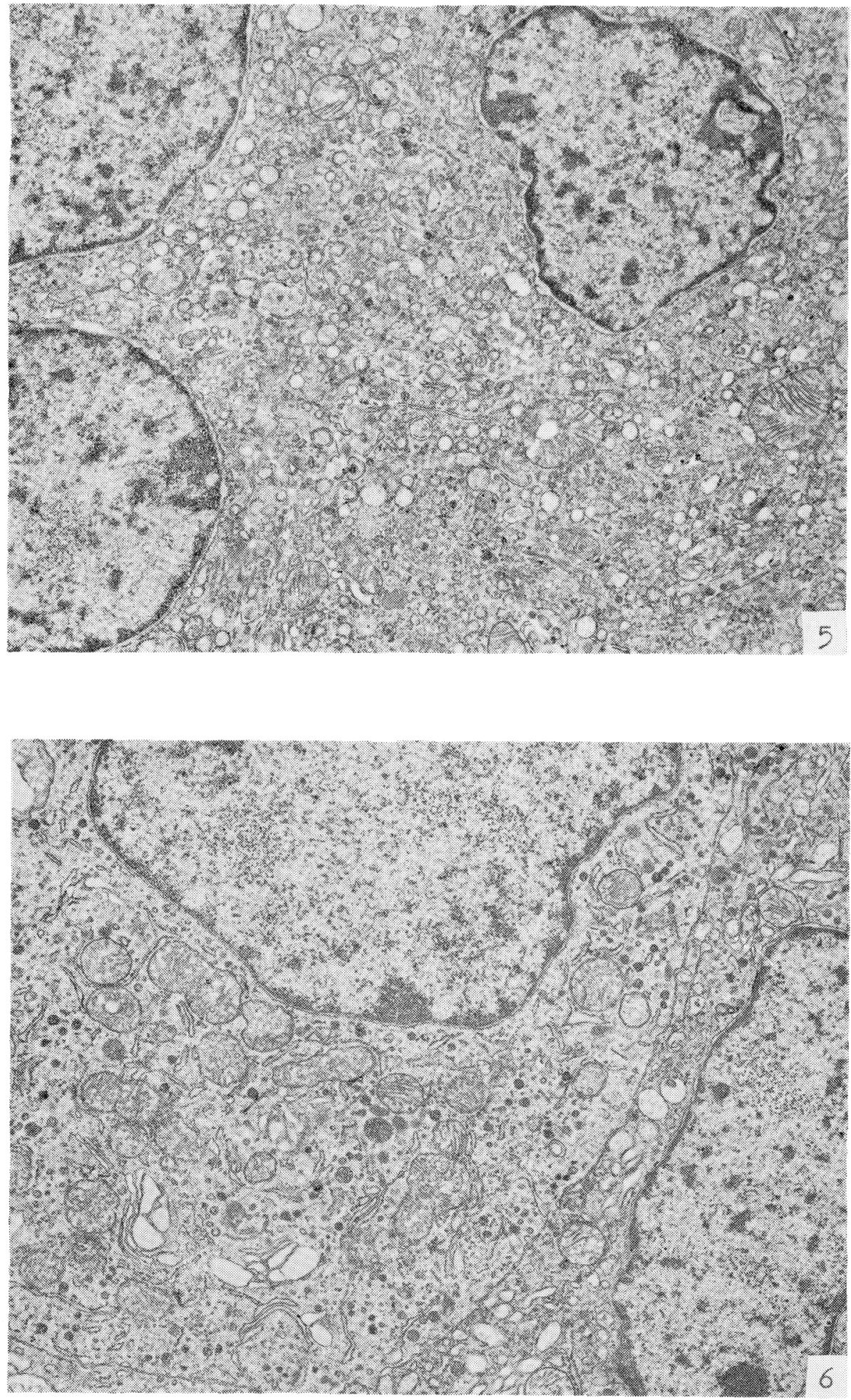